\title{
Hubungan Lama Paparan Sinar Matahari dengan Kadar 8- Hydroxy-2'-Deoxyguanosine Urin pada Remaja Perempuan
}

Rani Aulia Dwi Nanda ${ }^{1}$, Rahmatini², IImiawati²

\begin{abstract}
Abstrak
Salah satu bentuk predominan dari lesi oksidatif yang diinduksi oleh radikal bebas adalah 8-hidroksideoksiguanosin (8-OHdG). Paparan sinar matahari pada sel, terutama sel kulit dapat menyebabkan reaksi fotooksidasi yang terjadi akibat pelepasan reactive oxygen species (ROS). Lama paparan sinar matahari merupakan salah satu faktor penentu berapa banyak sel kulit yang mengalami stres oksidatif. Tujuan: Menganalisis hubungan lama paparan sinar matahari dengan kadar 8-OHdG urin pada remaja perempuan. Metode: Ini merupakan penelitian observasional analitik dengan desain cross-sectional dilakukan pada populasi mahasiswi Pendidikan Dokter Universitas Andalas dengan teknik systematic random sampling $(n=110)$. Lama paparan sinar matahari diperoleh melalui kuesioner dan kadar 8-OHdG diukur dengan metode ELISA. Analisis data dilakukan dengan uji Kruskal-Wallis. Hasil: Rerata usia subjek pada penelitian ini adalah 20,6 \pm 1,23 tahun, rerata lama paparan sinar matahari didapatkan sebesar 49,01 \pm 36,96 menit. Rerata kadar 8-OHdG pada subjek adalah 40,75 $\pm 39,62 \mathrm{ng} / \mathrm{ml}$. Analisis bivariat menunjukkan bahwa lama paparan sinar matahari tidak berhubungan dengan kadar $8-\mathrm{OHdG}$ urin $(p=0,396)$. Simpulan: Tidak terdapat hubungan antara lama paparan sinar matahari dengan kadar 8-OHdG urin pada remaja perempuan.
\end{abstract}

Kata kunci: 8-OHdG urin, lama paparan sinar matahari, stres oksidatif

\section{Abstract}

8-hydroxy-deoxyguanosine (8-OHdG) is among predominants of oxidative stress lesion induced by free radicals. Sun exposure to cells, especially skin cells can cause photooxidation which occurs due to reactive oxygen species (ROS) release. Duration of sunlight exposure is amongst determinants of oxidative stress degree in skin cells. Objectives: To analyzed the correlation between the duration of sunlight exposure and urinary 8-OHdG level in female young adults. Methods: This research was an analytic cross sectional study on female medical students of Andalas University selected by systematic random sampling $(n=110)$. Duration of sunlight exposure was collected using questionnaire and urinary 8-OHdG was measured by ELISA. Statistical analysis was performed by Kruskal-Wallis test. Results: Average age of subjects was $20.63 \pm 1.23$ (mean $\pm S D$ ) years, average duration of sunlight exposure was $49.01 \pm 36.96$ minutes. Levels of urinary $8-O H d G$ in our subjects was $40.75 \pm 39.62 \mathrm{ng} / \mathrm{ml}$. Bivariate analysis showed there was no significant correlation between duration of sunlight exposure and urinary 8-OHdG level $(p=0.396)$. Conclusion: There is no correlation with urinary 8-OHdG level in female young adults.

Keywords: duration of sunlight exposure, oxidative stress, urinary 8-OHdG

Affiliasi penulis: 1. Prodi Pendidikan Dokter, Fakultas Kedokteran, Universitas Andalas, Padang, Indonesia 2. Bagian Farmakologi, Fakultas Kedokteran, Universitas Andalas, Padang, Indonesia

Korespondensi: Rani Aulia Dwi Nanda, Email: rani.aulia56@gmail.com, Telp: +6285766068881

\section{PENDAHULUAN}

Indonesia merupakan salah satu negara tropis yang mendapat sinar matahari sepanjang tahunnya. Sinar matahari ini dapat menyebabkan radiasi berupa radiasi elektromagnetik pada tubuh terutama pada kulit. Radiasi sinar matahari terdiri dari berbagai panjang gelombang mulai dari sinar infra merah, sinar 
tampak, dan sinar ultraviolet (UV). Sinar matahari mengandung 3 jenis sinar ultraviolet yaitu UVA, UVB, dan UVC yang memiliki panjang gelombang berbeda. ${ }^{1}$

Kulit adalah bagian tubuh pertama yang akan terpapar dengan semua unsur eksogen dari lingkungan hidup manusia. ${ }^{2}$ Pada penelitian epidemiologi, paparan sinar matahari berhubungan dengan perkembangan dari berbagai kelainan yang berhubungan dengan kulit termasuk kanker. ${ }^{3}$ Penelitian eksperimental mengungkapkan bahwa sinar UV adalah faktor penyebab utama penyakit yang berhubungan dengan kulit termasuk kanker. ${ }^{4}$ Pajanan sinar matahari pada sel hidup dapat menyebabkan berbagai reaksi fotokimiawi seperti fotoadisi, fotoisomerasi, dan fotooksidasi. Reaksi fotooksidasi terjadi akibat pelepasan reactive oxygen species (ROS). Peningkatan ROS akan menyebabkan stres oksidatif yang akan berimplikasi pada berbagai macam penyakit, termasuk kanker. ${ }^{5}$

Di Indonesia sendiri, data registrasi kanker berbasis rumah sakit maupun berbasis populasi khususnya kanker kulit masih belum lengkap. Hal tersebut mengakibatkan data epidemiologi kanker kulit di Indonesia masih kurang. ${ }^{6}$ Di Amerika, berdasarkan data CDC dari tahun 1999-2014 kanker kulit menduduki posisi sebagai kanker yang paling sering ditemui. ${ }^{7}$ Penelitian di RSUP dr. M. Djamil Padang tahun 2011 menunjukkan bahwa terdapat 43 kasus pasien kanker kulit yang dirawat di bangsal bedah RSUP dr. M. Djamil Padang, dimana kasus lebih banyak terdapat pada perempuan yaitu 24 kasus $(55,9 \%)$ dan lokasi terbanyak pada wajah yaitu sebanyak 21 kasus (44,8\%). ${ }^{8}$

Senyawa 8-Hidroksi-deoksiguanosin (8-OHdG) adalah salah satu bentuk predominan dari lesi oksidatif yang diinduksi oleh radikal bebas. Tidak hanya itu, 8-OHdG juga telah digunakan sebagai biomarker untuk menilai kerusakan DNA endogen akibat stres oksidatif. ${ }^{3}$ Sinar matahari dan radiasi UV telah dilaporkan sebagai faktor risiko meningkatnya kadar 8-OHdG urin di sel epidermal kulit hewan maupun manusia secara in vivo. ${ }^{9}$ Radiasi UV dapat mengakibatkan oksidasi pada gugus basa DNA sel kulit, reaksi oksidasi pada gugus basa DNA sel inilah yang akan membentuk senyawa 8-hidroksideoksiguanosin (8-OHdG). ${ }^{10}$ Salah satu cara untuk mendeteksi kadar 8-OHdG pada tubuh seseorang adalah melalui jalur ekskresinya, yaitu urin. ${ }^{11}$

Perbedaan hormonal pada laki-laki dan perempuan terutama pada usia remaja memiliki peran dalam perbedaan struktur biologis kulit laki-laki dan perempuan. Hormon testosteron pada laki-laki menyebabkan kulit laki-laki lebih tebal dibanding perempuan, ini berarti kulit laki-laki memiliki kolagen dan elastin yang lebih padat dibanding perempuan. Kolagen dan elastin seperti telah diketahui memiliki kontribusi pada proses penuaan. Radikal bebas yang disebabkan oleh radiasi UV dapat menjadi faktor utama yang berpengaruh dalam kerusakan sel dan dapat menimbulkan kerusakan protein dan asam amino yang merupakan struktur utama kolagen dan jaringan elastin. Hal ini menunjukkan bahwa paparan sinar matahari pada perempuan bukan hanya dapat meningkatkan faktor risiko kanker kulit, tetapi juga dapat meningkatkan faktor risiko penuaan dini. ${ }^{12}$

Penelitian terdahulu telah menunjukkan adanya korelasi antara paparan sinar matahari dan kadar 8OHdG urin. Penelitian yang dilakukan pada siswa SD di Yogyakarta menunjukkan adanya korelasi kuat antara pigmentasi cepat setelah berolah raga di bawah terik matahari dengan peningkatan kadar 8OHdG urin. ${ }^{5}$ Selain itu, penelitian pada dewasa muda usia 20-24 tahun di Jepang menunjukkan adanya korelasi signifikan antara intensitas sinar matahari dengan meningkatnya kadar 8-OHdG urin. ${ }^{13}$

Berdasarkan penelitian di atas, proses stres oksidatif pada sel kulit manusia akibat radiasi UV dari sinar matahari dapat memengaruhi kadar 8-OHdG dalam tubuh melalui proses stres oksidatif. Selain itu, sinar UV merupakan faktor penyebab utama penyakit yang berhubungan dengan kulit termasuk kanker. ${ }^{4}$ Lama paparan dari sinar matahari pada tubuh seseorang dapat menjadi salah satu faktor penentu berapa banyak sel kulit yang mengalami stres oksidatif. Oleh karena itu perlu dianalisis tentang hubungan lama paparan sinar matahari dengan kadar 8-OHdG urin pada remaja perempuan.

\section{METODE}

Penelitian ini merupakan penelitian observasional analitik dengan rancangan cross sectional. Variabel dependen dalam penelitian ini 
adalah kadar 8-OHdG urin sedangkan variabel independen adalah lama paparan sinar matahari. Penelitian ini dilakukan pada bulan Februari-Maret 2018 di Fakultas Kedokteran Universitas Andalas. Populasi penelitian ini adalah seluruh mahasiswa perempuan remaja pada Program Studi Pendidikan Profesi Dokter Fakultas Kedokteran Universitas Andalas. Subjek yang memenuhi kriteria inklusi adalah perempuan remaja akhir yang berumur 18-23 tahun, etnis Minangkabau, tidak mempunyai riwayat penyakit jantung, hipertensi, diabetes mellitus, tiroid, hati, paruparu, bersedia menjadi subjek penelitian, dan tidak pernah berdomisili di daerah non tropis dalam 1 bulan yang lalu. Subjek yang memenuhi kriteria inklusi dikeluarkan apabila tidak dapat hadir saat wawancara dan pengambilan sampel urin. Data lama paparan sinar matahari diperoleh dengan cara wawancara. Pemeriksaan laboratorium dilakukan untuk memperoleh data kadar $8-\mathrm{OHdG}$ dan berat jenis urin subjek. Data dianalisis secara statistik menggunakan analisis univariat dan bivariat. Hubungan antara kadar 8-OHdG urin dengan lama paparan sinar matahari dianalisis dengan menggunakan uji Kruskal-Wallis dan dikatakan bermakna bila $\mathrm{p}<0.05$.

\section{HASIL}

Pelaksanaan penelitian ini dimulai dari bulan Februari sampai dengan Maret 2018 di Fakultas Kedokteran Universitas Andalas dan Laboratorium Biomedik Fakultas Kedokteran Universitas Andalas. Penelitian ini dilakukan terhadap 110 responden yang telah memenuhi kriteria inklusi dan eksklusi.

\section{Karakteristik Subjek Penelitian}

Rerata umur subjek penelitian $20,63 \pm 1,23$ tahun dan persentase subjek penelitian dengan IMT normal sebanyak 56,4\%. Rerata kadar $8-O H d G$ urin subjek adalah 40,75 $\pm 39,62 \mathrm{ng} / \mathrm{ml}$; rerata lama paparan sinar matahari adalah 49,01 \pm 39,69 menit; persentase subjek penelitian yang lama paparannya $<22,875$ menit sebanyak 24,5\%, 22,875-37,5 menit sebanyak 26,4\%, 37,6-71,75 menit sebanyak 24,5\%, dan > 71,75 menit sebanyak 24,5\%. Karakteristik subjek penelitian disajikan pada Tabel 1.
Tabel 1. Karakteristik subjek penelitian

\begin{tabular}{|c|c|c|}
\hline Karakteristik & n (\%) & $\mathrm{AM} \pm \mathrm{SD}$ \\
\hline Umur (tahun) & $110(100)$ & $20,63 \pm 1,23$ \\
\hline \multicolumn{3}{|l|}{$I M T\left(\mathrm{~kg} / \mathrm{m}^{2}\right)$} \\
\hline Kurus $(<18,5)$ & $9(8,2)$ & \\
\hline Normal $(18,5-22,9)$ & $62(56,4)$ & \\
\hline Kegemukan $(23-24,9)$ & $15(13,0)$ & \\
\hline Pra-obesitas $(25-29,9)$ & $12(10,9)$ & \\
\hline Obesitas $(\geq 30)$ & $12(10,9)$ & \\
\hline Lama paparan sinar matahari (menit) & $110(100)$ & $49,01 \pm 39,69$ \\
\hline \multicolumn{3}{|l|}{ Kategori lama paparan matahari (menit) } \\
\hline $1 .<22,875$ & $27(24,5)$ & \\
\hline $2.22,875-37,5$ & $29(26,4)$ & \\
\hline 3. $37,6-71,75$ & $27(24,5)$ & \\
\hline 4. $>71,75$ & $27(24,5)$ & \\
\hline Kaddar 8-OHdG Urin $(n g / m l)$ & $110(100)$ & $40,75 \pm 39,62$ \\
\hline
\end{tabular}

$\mathrm{AM}=$ Arithmetic Mean $; \mathrm{SD}=$ Standard Deviation $; \mathrm{IMT}=$ Indeks Massa Tubuh

\section{Korelasi Lama Paparan Sinar Matahari dengan Kadar 8-OHdG Urin}

Analisis korelasi lama paparan sinar matahari dengan kadar 8-OHdG urin dilakukan dengan uji Kruskal-Wallis menunjukkan bahwa tidak terdapat perbedaan kadar 8-OHdG urin yang signifikan pada kelompok data lama paparan sinar matahari dengan nilai $p=0,396(p>0,05)$ yang disajikan pada Gambar 1. Rerata kadar $8-\mathrm{OHdG}$ urin subjek penelitian pada kelompok yang lama paparannya $<22,875$ menit adalah 50,84 $\pm 52,19 \mathrm{ng} / \mathrm{ml}$, pada kelompok lama paparan $22,875-37,5$ adalah $34,28 \pm 25,80 \mathrm{ng} / \mathrm{ml}$, pada kelompok lama paparan 37,6-71,75 menit adalah $45,63 \pm 48,61 \mathrm{ng} / \mathrm{ml}$, dan pada kelompok lama paparan > 71,75 menit adalah 32,73 $\pm 23,07 \mathrm{ng} / \mathrm{ml}$.

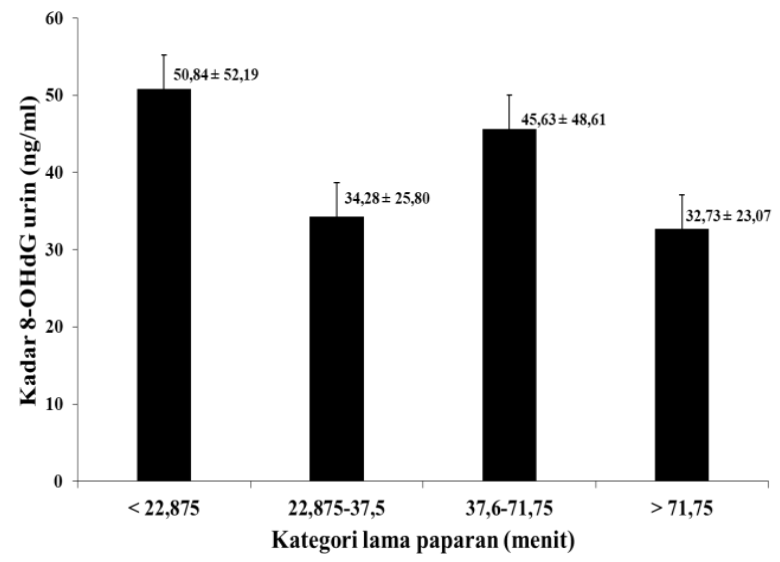

Gambar 2. Perbedaan kadar $8-O H d G(A M \pm S D)$ urin menurut kategori lama paparan sinar matahari 


\section{PEMBAHASAN}

Subjek dalam penelitian ini cukup homogen dari aspek usia dan etnis yaitu perempuan remaja akhir yang berusia 18-23 tahun dengan etnis Minangkabau. Berdasarkan hasil analisis diperoleh bahwa rerata umur 20,63 $\pm 1,23$ tahun.

Kadar 8-OHdG urin pada penelitian ini diukur dengan Elabscience 8-OHdG ELISA kit yang telah digunakan pada penelitian terdahulu. ${ }^{14}$ Pemeriksaan berat jenis urin subjek penelitian dilakukan dengan menggunakan urinometer. Hasil kadar 8-OHdG dari spektofotometri kemudian dinormalisasi dengan berat jenis urin sampel untuk menghindari bias kadar 8OHdG akibat fluktuasi urin.

Uji korelasi Kruskal-Wallis menunjukkan tidak terdapat hubungan yang signifikan antara lama paparan sinar matahari dengan kadar 8-OHdG urin. Hal ini sesuai dengan hasil penelitian terdahulu yang dilakukan di Jepang pada tahun 2011 dengan subjek sebanyak 127 orang dewasa muda. Penelitian tersebut mengungkapkan bahwa terdapat hubungan yang signifikan antara intensitas matahari dengan kadar 8OHdG urin, tetapi tidak terdapat hubungan yang signifikan dengan lama paparan dan luas tubuh yang terpapar matahari. ${ }^{13}$

Penelitian sebelumnya telah mengungkapkan bahwa paparan sinar matahari merupakan salah satu faktor yang dapat menyebabkan kerusakan DNA. ${ }^{15}$ Penelitian terdahulu juga menemukan hubungan pemulihan DNA oksidatif yang diinduksi dengan peningkatan kadar $8-\mathrm{OHdG}$ urin. ${ }^{5}$ Penelitian tersebut dilakukan pada siswa sekolah dasar $(n=30)$ yang mengikuti olahraga di bawah sinar terik matahari. Sampel urin subjek diambil 24 jam sebelum dan 24 jam setelah subjek berolahraga di bawah terik matahari. Hasil yang ditemukan adalah setelah subjek berolahraga di bawah terik matahari terjadi peningkatan kadar $8-\mathrm{OHdG}$ urin yang bermakna $(\mathrm{p}<$ $0,01)$.

Subjek dalam penelitian ini memiliki kebiasaan berpakaian serta aktivitas harian yang homogen sehingga dapat meminimalkan bias atau faktor pengganggu yang tidak diteliti pada penelitian ini. Penelitian ini menggunakan Elabscience 8-OHdG ELISA kit yang telah digunakan pada penelitian sebelumnya terkait $8-\mathrm{OHdG}$ urin $^{14}$ dan memiliki sertifikat quality control untuk menjamin keakuratan data. Sampel urin diperiksa secara duplo untuk meningkatkan keandalan data penelitian. Jumlah subjek pada penelitian ini relatif lebih besar dibandingkan penelitian serupa terhadap kadar 8OHdG urin di Indonesia (Mustikaningsih et al, 2005, n= $30)^{5}$ dan serupa dengan penelitian terdahulu di Jepang (Kato et al, 2011, $\mathrm{n}=127$ ). ${ }^{13}$ Pengambilan data lama paparan pada penelitian ini diambil selama dua hari, yang menurut penelitian sebelumnya mengungkapkan peningkatan maksimal kadar 8OHdG pada kulit terjadi 24-48 jam setelah paparan UVB dari sinar matahari. ${ }^{13}$

Subjek penelitian yang bersifat homogen juga dapat menjadi keterbatasan penelitian dalam analisis variabel lama paparan sinar matahari. Pada penelitian ini, peneliti tidak mengumpulkan data asupan diet subjek penelitian. Banyak penelitian sebelumnya telah membuktikan peran jenis asupan diet sebagai prediktor kadar 8-OHdG, salah satunya adalah konsumsi asam arakidonat yang terdapat pada daging memiliki pengaruh signifikan terhadap peningkatan kadar 8 -OHdG. ${ }^{16}$ Peneliti juga tidak mengumpulkan data mengenai kebiasaan merokok dan riwayat terpapar asap rokok lingkungan dari subjek penelitian, dimana faktor ini dapat menjadi salah satu faktor yang memicu stres oksidatif. ${ }^{17}$

\section{SIMPULAN}

Tidak terdapat hubungan antara lama paparan sinar matahari dengan kadar 8-OHdG urin pada remaja perempuan. Perlu diteliti faktor-faktor lain yang mempengaruhi kadar 8-OHdG urin.

\section{UCAPAN TERIMA KASIH}

Terima kasih kepada Elwitri Silvia dan Indah Khoirunn Nisa atas kolaborasi dalam pengumpulan data. Peneliti juga berterimakasih kepada Juane Plantika Menra atas bantuan teknis dalam pemeriksaan laboratorium kadar 8-OHdG urin.

\section{DAFTAR PUSTAKA}

1. D'Orazio J, Jarrett S, Amaro-Ortiz A, Scott T. UV radiation and the skin. Int J Mol Sci. 2013;14(6): 12222-48 
2. Narendhirakannan RT, Hannah MAC. Oxidative stress and skin cancer: an overview. Ind J Clin Biochem. 2013;28;(2):110-5.

3. Pilger A, Rüdiger HW. 8-Hydroxy2'deoxyguanosine as a marker of oxidative DNA damage related to occupational and environmental exposures. Int Arch Occup Environ Health. 2006; 80:1-15

4. Marrot L, Meunier JR. Skin DNA photodamage and its biological consequences. J Am Acad Dermatol. 2008;58:139-48.

5. Mustikaningsih R, Wirohardidjojo $\mathrm{Y}$, Radiono $\mathrm{S}$. Hubungan antara pigmentasi cepat dengan kemampuan pemulihan DNA oksidatif; kajian pada pelajar SD yang berolahraga di bawah terik matahari. B.I.Ked. 2005;37:74-9.

6. Aida SD. Epidemiologi kanker kulit. Perdoski. 2011;33:61-2.

7. US Cancer Statics Working Group. United States Cancer Statics: 1999-2014 incidence and mortality web-based report. Atlanta (GA): department of health and human services, centre for disease control and prevention, and national cancer institute; 2017 (diakses 10 Oktober 2017). Tersedia dari: http://www.cdc.gov/uscs

8. Azamris. Kanker kulit di bangsal bedah RS Dr. M. Djamil Padang Januari 2002 - Maret 2007. CDK. 2011;38(2):109-10.

9. Beehler BC, Przybyszewski J, Box HB, Kulesz MF. Formation of 8-hydroxydeoxyguanosine within DNA of mouse keratinocytes exposed in culture to UVB and $\mathrm{H}_{2} \mathrm{O}_{2}$. Carcinogenesis. 1992;13:2003-7.

10. Valavanidis A, Vlahogianni T, Fiotakis C. 8Hydroxy-2'-deoxyguanosine (8-OHdG): a critical biomarker of oxidative stress and carcinogenesis. J Environ Sci Health C Environ Carcinog Exotoxicol Rev. 2009;27:120-39.

11. Matsumoto $Y$, Ogawa $Y$, Yoshida R, Shimamori A, Kasai $\mathrm{H}$, Ohta $\mathrm{H}$. The stability of the oxidative stress marker, urinary 8-hydroxy-2'deoxyguanosine $(8-\mathrm{OHdG})$, when stored at room temperature. J Occup Health. 2008;50:366-72.

12. Fisher GJ, Sewon K, Varani J, Bata-Csorgo Z, Wan $\mathrm{Y}$, Datta $\mathrm{S}$, et al. Mechanisms of photoaging and chronological skin aging. Arch Dermatol. 2002;138(11):1462-70.

13. Kato $M$, lida $M$, Goto $Y$, Kondo $T$, Yajima I. Sunlight exposure-mediated DNA damage in young adults. Cancer Epidemiology Biomarkers and Prevention. 2011;20(8):1622-8.

14. Indraprasta S, Zulkarnain I, Ervinanti E. Peningkatan kadar 8-hydroxydeoxyguanosine (8OHdG) urine pada pasien dermatitis atopik anak. Berkala IImu Kesehatan Kulit dan Kelamin. 2016;28(3).

15. Steinberg ML, Hubbard K, Utti C, Clas B, Hwang BJ, Hill HZ, Orlow I. Patterns of persistent DNA damage associated with sun-exposure and the glutathione $S$-transferase M1 genotype in melanoma patients. Photochem Photobiol. 2009;85:379-86.

16. Thomson C, Giuliano A, Shaw J, Rock C, Ritenbaugh C, Hakim I, et al. Diet and biomarkers of oxidative damage in women previously treated for breast cancer. Nutr Cancer. 2005;51(2):146-54.

17. Fitria, Triandhini R, Mangimbulude JC, Karwur FF. Merokok dan oksidasi DNA. Sains Medika. 2013;5(2):113-20. 